\title{
Growth, survival, and body composition of rainbow trout, Oncorhynchus mykiss, when dietary fish meal is replaced with silkworm (Bombyx mori) pupae
}

\author{
Matin Shakoori, Hamed Gholipour, Samira Naseri, Hossein Khara
}

Received - 03 March 2015/Accepted - 29 January 2016. Published online: 31 March 2016; Inland Fisheries Institute in Olsztyn, Poland Citation: Shakoori M., Gholipour H., Naseri S., Khara H. 2016 - Growth, survival, and body composition of rainbow trout, Oncorhynchus mykiss, when dietary fish meal is replaced with silkworm (Bombyx mori) pupae - Arch. Pol. Fish. 24: 53-57

\begin{abstract}
The effects of substituting fishmeal (FM) with different quantities of silkworm pupae (SP) on the growth, survival, and body composition of rainbow trout, Oncorhynchus mykiss (Walbaum), were investigated over the course of a 60-day experiment. A total of 360 fingerlings $(55 \pm 3.42 \mathrm{~g})$ were randomly allotted to four treatment groups (T1 - fish fed 52.5\% FM; T2 - fish fed 5\% SP + 47.5\% FM; T3 - fish fed $10 \%$ SP+ 42.5\% FM; T4 - fish fed 15\% SP + 37.5\% FM). Each treatment group was divided into three replicates of 30 fish per replicate. One group served as the control. At the end of the experiment, the results showed that $10 \%$ of FM can be replaced with SP without any adverse effects on the values of the feed conversion ratio (FCR), specific growth rate (SGR), weight gain percent (WG), condition factor $(\mathrm{CF})$, survival rate (SR), protein content, lipid content, or nutrition protein utilization (NPU).
\end{abstract}

Keywords: fishmeal, silkworm pupae, growth, survival, body composition, rainbow trout

\footnotetext{
M. Shakoori [ $\left.\Xi^{-}\right]$, H. Gholipour

Young Researchers Club and Elite, Ghaemshahr Branch

Islamic Azad University, Ghaemshahr, Iran

e-mail: matin.shakoori@yahoo.com

S. Naseri

Young Researchers Club and Elite, Lahijan Branch,

Islamic Azad University, Lahijan, Iran

H. Khara

Department of Agriculture, Faculty of Natural Resources, Lahijan

Branch, Islamic Azad University, Lahijan, Iran
}

\section{Introduction}

Rainbow trout, Oncorhynchus mykiss (Walbaum) is one of the most widely cultured species in world, including in Iran. Demand for commercial diets has increased because of the rapid expansion of rainbow trout culture in several parts of Iran. Presently, FM is used widely as an integral part of commercial diets to meet the protein requirements of cultured rainbow trout. Nevertheless, FM is very expensive, and it increases the costs of rainbow trout aquaculture. During the past decades, numerous attempts have been made to substitute FM with other inexpensive protein sources. These have included soybeans (Oliva-Teles et al. 1994, Kaushik et al. 1995), maize gluten meal (Wu et al. 1995), lupins (Fontainhas-Fernandes et al. 1999), rapeseed (Davies et al. 1990), cottonseed meal (Rinchard et al. 2002), corn gluten (Jahanbakhshi et al. 2012), and canola meal (Thiessen et al. 2004, Abbas et al. 2008). In addition to these sources, SP has been found to be one of the best substitutes for FM in the diets of some cultured fish species, especially carps (Nandeesha et al. 1999, Nandeesha et al. 2000, Rangacharyulu et al. 2003). These studies have reported that dietary FM could be replaced with various quantities of SP without adverse effects on

\footnotetext{
(c) Copyright by Stanisław Sakowicz Inland Fisheries Institute in Olsztyn.

(c) 2016 Author(s). This is an open access article licensed under the Creative Commons Attribution-NonCommercial-NoDerivs License (http://creativecommons.org/licenses/by-nc-nd/3.0/).
} 
growth or survival parameters. To our knowledge, there is no information about the possibility of replacing FM with SP as a protein source in the rainbow trout diet. Thus, the aim of this study was to examine the effects different quantities of SP as a constituent protein source had on growth, survival, and body composition of rainbow trout. This study could be useful in designating a cost-effective protein source for rainbow trout.

\section{Material and methods}

The experiment was carried out for a period of 60 days at the Cold-Water Fisheries Research Center in Tonekabon, Iran. A total of 360 rainbow trout fingerlings ( $55 \pm 3.42 \mathrm{~g}$ ) were randomly allotted to four treatment groups with three replicates of 30 fish per replicate: $\mathrm{T} 1-52.5 \% \mathrm{FM}$; T2 - 5\% SP $+47.5 \%$ FM; T3 - 10\% SP+ 42.5\% FM; T4 - 15\% SP + 37.5\% FM. The fingerlings were stocked into $300 \mathrm{~L}$ polyethylene tanks at a stocking rate of 30 fish per tank. During the experiment, the water temperature was $16-18^{\circ} \mathrm{C}$, dissolved oxygen was $8-9 \mathrm{mg} \mathrm{L}^{-1}$, and $\mathrm{pH}$ was 7.3-7.5. The experimental diet was prepared according to National Research Council recommendations for rainbow trout (Table 1). To prepare the experimental diet, first, all of the ingredients were pulverized and then mixed to homogenize. After this, the homogenized ingredients were mixed again with some $80^{\circ} \mathrm{C}$ water for $30 \mathrm{~min}$ to prepare the feed for shaping. Finally, dry pellets $3.5 \mathrm{~mm}$ in diameter were made by a pelleting machine. A feeding ration of $2.3 \% \mathrm{~kg}_{\text {body weight }}{ }^{-1}$ was determined for daily feeding based on a standard feeding schedule. The fish were fed three times per day. To investigate the growth and survival of fish and also to determine feeding ration, biometric measurements were recorded 6 times at 10-day intervals throughout the experiment. Each time, 10 fish were captured randomly and parameters including specific growth rate (SGR), weight gain percent (WG), condition factor (CF), feed conversion ratio (FCR), and survival rate (SR) were calculated (Lagler et al. 1962, Helland et al. 1996, Ghosh et al. 2003)

\section{Body composition assays}

After 60 days of the experiment, 9 fish from each treatment were selected randomly for body composition analysis, which was carried out according to

Table 1

Composition of dietary ingredients in the experimental diet

\begin{tabular}{lllll}
\hline \hline Ingredients (\%) & Diet 1 & Diet 2 & Diet 3 & Diet 4 \\
\hline \hline Corn flour & 10.5 & 12.4 & 14.35 & 16.3 \\
Soybean flour & 20.0 & 20.5 & 21 & 21.5 \\
Fish meal & 52.5 & 47.5 & 42.5 & 15.5 \\
Silkworm pupae & 0.0 & 5.0 & 10.0 & 4.7 \\
Soybean oil & 12.0 & 9.6 & 7.15 & 1.0 \\
Mineral supplement mixture & 1.0 & 1.0 & 1.0 & 1.0 \\
Vitamin supplement mixture & 1.0 & 1.0 & 1.0 & 1.5 \\
Binder & 1.5 & 1.5 & 1.5 & 0.03 \\
Antioxidant & 0.03 & 0.03 & 0.03 & 0.1 \\
Vitamin C & 0.1 & 0.1 & 0.1 & 0.25 \\
Choline chloride & 0.25 & 0.25 & 0.25 & 1.0 \\
Dicalcium phosphate & 1.0 & 1.0 & 1.0 & 0.12 \\
Anti-fungal chemicals & 0.12 & 0.12 & 0.12 & 100 \\
Total & 100 & 100 & 100 & \\
\hline \hline
\end{tabular}


Table 2

Comparison of survival and growth parameters among experimental fish groups fed various quantities of silkworm pupae (T1 $52.5 \%$ FM; T2 - 5\% SP + 47.5\% FM; T3 - 10\% SP+ 42.5\% FM; T4 - 15\% SP + 37.5\% FM)

\begin{tabular}{lllll}
\hline \hline Parameters & Group T1 & Group T2 & Group T3 & Group T4 \\
\hline \hline CF & $0.93 \pm 0.11^{\mathrm{a}}$ & $0.94 \pm 0.1^{\mathrm{a}}$ & $0.93 \pm 0.12^{\mathrm{a}}$ & $0.92 \pm 0.1^{\mathrm{a}}$ \\
SR & $99 \pm 1.3^{\mathrm{a}}$ & $98 \pm 2.5^{\mathrm{a}}$ & $97 \pm 1.5^{\mathrm{a}}$ & $98 \pm 1.2^{\mathrm{a}}$ \\
SGR & $0.23 \pm 0.05^{\mathrm{a}}$ & $0.17 \pm 0.04^{\mathrm{b}}$ & $0.18 \pm 0.05^{\mathrm{ab}}$ & $0.175 \pm 0.03^{\mathrm{b}}$ \\
WG & $14.5 \pm 2^{\mathrm{a}}$ & $12.4 \pm 1.7^{\mathrm{b}}$ & $12.5 \pm 2.1^{\mathrm{ab}}$ & $12.7 \pm 1.8^{\mathrm{b}}$ \\
FCR & $0.82 \pm 0.015^{\mathrm{a}}$ & $0.857 \pm 0.016^{\mathrm{b}}$ & $0.838 \pm 0.018^{\mathrm{ab}}$ & $0.9 \pm 0.02^{\mathrm{c}}$ \\
PER & $1.9 \pm 0.4^{\mathrm{a}}$ & $2.05 \pm 0.42^{\mathrm{a}}$ & $1.8 \pm 0.45^{\mathrm{a}}$ & $1.7 \pm 0.4^{\mathrm{a}}$ \\
NPU & $0.93 \pm 0.05^{\mathrm{a}}$ & $0.83 \pm 0.05^{\mathrm{b}}$ & $0.84 \pm 0.06^{\mathrm{ab}}$ & $0.82 \pm 0.06^{\mathrm{b}}$ \\
\hline \hline
\end{tabular}

Mean values in the same row with different letter indexes differ significantly statistically at a level of significance of $\mathrm{P} \leq 0.05$

Table 3

Comparison of meat quality parameters between experimental fish groups fed by various levels of silkworm pupae (T1: with 52.5\% FM; T2: 5\% SP + 47.5\% FM; T3: $10 \% \mathrm{SP}+42.5 \% \mathrm{FM}$ and T4: $15 \% \mathrm{SP}+37.5 \% \mathrm{FM})$

\begin{tabular}{llllll}
\hline \hline Parameters & Group T1 & Group T2 & Group T3 & Group T4 & Before experiment \\
\hline \hline Moisture (\%) & $73 \pm 7.5^{\mathrm{a}}$ & $68 \pm 6^{\mathrm{a}}$ & $69.5 \pm 6.5^{\mathrm{a}}$ & $68.5 \pm 6^{\mathrm{a}}$ & $74.5 \pm 5.5^{\mathrm{a}}$ \\
Lipid (\%) & $30 \pm 4.2^{\mathrm{a}}$ & $33.5 \pm 4^{\mathrm{a}}$ & $32.5 \pm 4.8^{\mathrm{a}}$ & $34.5 \pm 4.5^{\mathrm{a}}$ & $22.5 \pm 5^{\mathrm{b}}$ \\
Protein (\%) & $80 \pm 7.5^{\mathrm{a}}$ & $78.5 \pm 8^{\mathrm{a}}$ & $79.5 \pm 8.2^{\mathrm{a}}$ & $80 \pm 8.1^{\mathrm{a}}$ & $36 \pm 4.5^{\mathrm{b}}$ \\
Ash (\%) & $10.5 \pm 0.6^{\mathrm{b}}$ & $11.1 \pm 0.7^{\mathrm{b}}$ & $12.1 \pm 0.8^{\mathrm{a}}$ & $10.6 \pm 0.75^{\mathrm{b}}$ & $10.2 \pm 0.7^{\mathrm{b}}$ \\
\hline \hline
\end{tabular}

Mean values in the same row with different letter indexes differ significantly statistically at a level of significance of $\mathrm{P} \leq 0.05$

procedures described by AOAC (1995). Moisture was determined by drying samples at $105^{\circ} \mathrm{C}$ to a constant weight; total crude protein with the Kjeldahl method and a multiplier of 6.25; lipid content with the Soxhlet method with petroleum ether as the solvent for $8 \mathrm{~h}$; total ash content was measured by mineralizing samples at a temperature of $550^{\circ} \mathrm{C}$ for 8 hours (Linn Electo-therm Furnace). After protein assays, the protein efficiency ratio (PER) and nutrition protein utilization (NPU) values were calculated (Helland et al. 1996).

All data were subjected to one way analysis of variance (ANOVA) and means were separated by Duncan's multiple range test using SPSS software. Since the percentage data did not have a normal distribution, proportional data were converted by angular transformation $(\arcsin \sqrt{ } \mathrm{p})$. A significance level of 0.05 was used for data analysis.

\section{Results}

According to ANOVA analysis, there were no significant differences among experimental treatments in terms of CF, SR, PER (Table 2), moisture, lipid, or protein percentage (Table 3) of the carcass throughout the 60 days of the experiment $(\mathrm{P}>0.05)$. Significant differences were noted in the values of SGR, WG, and NPU among experimental treatments (Table $2, \mathrm{P}<0.05$ ). Values of SGR, WG, PER, and NPU were similar between groups T1 and T3 (Table 2, P > 0.05), although their values were significantly higher than those of the other experimental treatments $(\mathrm{P}<0.05)$. The FCR values were not statistically different between $\mathrm{T} 1, \mathrm{~T} 2$, and $\mathrm{T} 3$, although this parameter was higher in $\mathrm{T} 4$ than in the other treatments (Table 2). The highest values of carcass ash content were observed in T3 (Table 3, 
$\mathrm{P}<0.05$ ), while there were no significant differences among the other treatments $(\mathrm{P}>0.05)$.

\section{Discussion}

In the present study, our results showed that $10 \%$ of FM can be replaced with SP without any adverse effects on FCR, SGR, WG, CF, or SR values. In contrast, the incorporation of more than 10\% SP adversely reduced growth and increased the FCR. This clearly indicates that including SP in diets up to a quantity of $10 \%$ of FM can meet the essential requirements of rainbow trout for proper growth. It was found that SP has an appropriate ratio of essential amino acids, fatty acids, and other compounds required for growth, including antioxidants and vitamins (Kwon et al. 2012). The analyses of the carcass reveal that partial replacement of FM with SP may compensate to some extent for the reduction of the FM and that such a feed might still meet the nutritional requirements of rainbow trout. The similar values of protein content, PER, and NPU among fish that were fed with only FM and those fed a diet containing up to $10 \%$ SP might confirm this conclusion. It is reported that the body lipid concentration of fish is positively related to the levels of dietary lipids and energy (Takeuchi et al. 1978). In our study, similar lipid levels were observed among experimental treatments, and this indicates that SP oil was probably incorporated into the fish body. Nevertheless, in other fish species, such as common carp, it was found that the short-chain unsaturated fatty acids of the SP fat were utilized for energy demands (Nandeesha et al. 1999). The body ash content of rainbow trout was approximately similar among the experimental treatments, which indicates that SP had a neutral effect on meat quality. The moisture content of tissue is used mostly as an indicator of the nutritional condition of fish (Sargeut et al. 1989). In starved fish, as the lipid content of body tissues is used to provide energy, the moisture content of tissue increases from the oxidation of lipids and the resultant production of water and carbon dioxide (Sargeut et al. 1989). An inverse relationship between moisture and fat is reported in several studies (De Silva et al. 1991). In our study, the stable levels of body moisture among treatments could have stemmed from the fact that we did not examine any specimens from a starvation experiment.

In conclusion, our results indicate that $\mathrm{SP}$ can be incorporated into the diet for a period of 60 days even at quantities of up to $10 \%$ of FM without any adverse effect on the meat quality, growth, or survival of rainbow trout. However, a long-term trial is necessary to study long-term effects of SP on meat quality, growth, and survival.

Acknowledgment. The authors would like to acknowledge head and staff of the Cold-Water Fisheries Research Center in Tonekabon for technical assistance throughout the course of the study and for providing fish.

Author contributions. M.S. and H.K. designed the experiment; H.G. statistically analyzed the data, M.S., S.N. and H.K. wrote the manuscript.

\section{References}

AOAC 1995 - Association of Official Analytical Chemists, Official methods of analysis. 16 edition - AOAC, Arlington, VA, $1832 \mathrm{p}$.

Abbas S., Ahmed I., Hafeez-Ur-Rehman M., Mateen A. 2008 - Replacement of fish meal by canola meal in diets for major carps in fertilized ponds - Pakistan Vet. J. 28: 111-114.

Davies S.J., McConnell S., Bateson R.I., 1990 - Potential of rapeseed meal as an alternative protein source in complete diets for tilapia (Oreochromis mossambicus Peters) - Aquaculture, 87: 145-154.

De Silva S.S., Gunasekera R.M., Shim K.F. 1991 - Interactions of varying dietary protein and lipid levels in young red tilapia: evidence of protein sparing - Aquaculture, 95: 305-318.

Fontainhas-Fernandes A., Gomes A., Reis-Henriques M.A., Coimbra J. 1999 - Replacement of fish meal by plant proteins in the diet of Nile tilapia: digestibility and growth performance - Aquacult. Int. 7: 57-67.

Ghosh K. Kumar S.K., Kumar R.A. 2003 - Supplementation of an isolated fish gut bacterium, Bacillus circulans, in: formulated diets for Rohu, Labeo rohita, fingerlings - Isr. J. Aquac.-Bamidgeh, 55: 13- 21. 
Helland S.J., GrisdaleHelland B., Nerland S., 1996 - A simple method for the measurement of daily feed intake of groups of fish in tanks - Aquaculture, 139: 157-163.

Jahanbakhshi A., Ramazi F.G. Soudagar M. 2012 - Effects of dietary corn gluten supplementation on body composition and growth performance in common carp (Cyprinus carpio) juvenile - Global Vet. 9: 85-88.

Kaushik S.J., Cravedi J.P., Lalles J., Sumpter B., Fauconneau M., Laroche M. 1995 - Partial or total replacement of fish meal by soybean protein on growth, protein utilization, potential estrogenic or antigenic effects, cholesterolemia and flesh quality in rainbow trout - Aquaculture, 133: 257-274.

Kwon M.G., Kim D.S., Lee J.H., Park S.W., Choo Y.K., Han Y.S., Kim J.S., Hwang K.A., Ko K., Kisung K. 2012 - Isolation and analysis of natural compounds from silkworm pupae and effect of its extracts on alcohol detoxification Entomol. Res. 42: 55-62.

Lagler K.F., Bardach J.E., Miller R.R. 1962. Ichthyology John Wiley and Sons. Inc., New York.

Nandeesha M.C., Gangadhara B., Manissery J.K. 1999 - Silkworm pupae oil and sardine oil as an additional energy source in the diet of common carp, Cyprinus carpio Asian Fish. Sci. 12: 207-215.

Nandeesha M.C., Gangadhara B., Varghese T.J., Keshavanath P. 2000 - Growth response and flesh quality of common carp, Cyprinus carpio fed with high levels of nondefatted silkworm pupae - Asian Fish. Sci. 13: 235-242.

Oliva-Teles A., Gouveia A.J., Gomes E., Rema P. 1994 - The effect of different processing treatments on soybean meal utilization by rainbow trout, Oncorhynchus mykiss Aquaculture, 124: 343-349.

Rangacharyulu P.V., Giri S.S., Paul B.N., Yashoda K.P., Jagannatha Rao R., Mahendrakar N.S., Mohanty S.N., Mukhopadhyay P.K. 2003 - Utilization of fermented silkworm pupae silage in feed for carps - Bioresource Technol. 86: 29-32.

Rinchard J., Mbahinzireki G., Dabrowski K., Lee K.J., Garcia-Abiado M.A., Ottobre J. 2002 - Effects of dietary cottonseed meal protein level on growth, gonad development and plasma sex steroid hormones of tropical fish tilapia Oreochromis sp. - Aquacult. Int. 20: 11-28.

Sargent J., Henderson R.J., Tocher D.R. 1989 - The lipids In: Fish Nutrition (Ed.) J.E. Halver, Academic Press, San Diego: 153-218.

Takeuchi T., Watanabe T., Ogino C. 1978 - Optimum ratio of protein to lipid in diets in rainbow trout - Bull. Japan Soc. Sci. Fish. 44: 683-688.

Thiessen D.L., Maenz D.D., Newkirk H.L., Classen H.L., Drew M.D. 2004 - Replacement of fishmeal by canola protein concentrate in diets fed to rainbow trout (Oncorhynchus mykiss) - Aquacult. Nut. 10: 379-388.

Wu H., Liu X., Jaenisch R., Lodish H.F. 1995 - Generation of committed erythroid BFU-E and CFU-E progenitors does not require erythropoietin or the erythropoietin receptor Cell 83: 59-67. 